\title{
THE EFFECT OF MASS OF COAL FLY ASH-CHITOSAN COMPOSITE PELLETS MODIFIED WITH GLUTARALDEHYDE ON THE ADSORPTION OF MERCURY IN SOLUTION
}

\author{
${ }^{1}$ Isna Syauqiah, ${ }^{2}$ Umi Baroroh Lili Utami, ${ }^{3}$ Meina Wulansari Yusniar \\ ${ }^{1}$ Chemical Engineering Department, Engineering Faculty \\ ${ }^{2}$ Chemical Department, Mathemathics and Sciences Faculty \\ Lambung Mangkurat University, Banjarbaru, South Kalimantan, Indonesia \\ ${ }^{3}$ Master of Management Department, Economic and Business Faculty \\ Lambung Mangkurat University, Banjarmasin, South Kalimantan, Indonesia
}

\section{Email : isnatk@gmail.com}

\begin{abstract}
Fly ash can be used and utilized as an adsorbent because it is cheap and effective to adsorb waste in the aquatic environment. $\mathrm{Hg}$ also known as Mercury is a carciogenic heavy metal and potentially threatens human health at very low concentrations. In this study, fly ash was applied as the adsorbent for $\mathrm{Hg}^{2+}$ in the form of chitosan-fly ash composite pellet and was cross-linked with glutaraldehyde in order to know how much the mass of pellets that can be used to lower the concentration of $\mathrm{Hg}^{2+}$ in solution. The results showed that the fly ash can be compositated with chitosan gel after going through the process of physical-chemical activation so that it can be formed into adsorbent pellets/granules. The optimum condition was obtained from adsorbent pellets of fly ash-chitosan composite crosslinked with glutaraldehyde after contacted with a solution containing $\mathrm{Hg}^{2+}$ with the pellet mass of $3 \mathrm{~g}$.
\end{abstract}

Keywords: composite, fly ash, glutaraldehyde, pellets

\section{INTRODUCTION}

Fly ash can be used and utilized as an adsorbent because it is cheap and effective to adsorb waste in the aquatic environment (Ramadan et al., 2010). The main component of fly ash is silica $\left(\mathrm{SiO}_{2}\right)$, alumina $\left(\mathrm{Al}_{2} \mathrm{O}_{3}\right)$, iron oxide $\left(\mathrm{Fe}_{2} \mathrm{O}_{3}\right)$ and a number of unburnt carbon. These components have an important role in the adsorption process (Wang and Wu, 2006). Fly ash absobent was used to adsorb phenolic compounds (Aksu and Yener, 1999), together with two types of compounds, polychlorinated biphenyls (PCBs), namely 2,3,4-trichlorobiphenyl and 2,2,3,3,4,5,6-heptachlorobiphenyl (Nollet et al., 2003). Fly ash can also be used as an adsorbent for $\mathrm{Ni}$ (II) and $\mathrm{Cu}$ (II) (Soco and Kalembkiewicz, 2013), Zn (II) (Wang et al., 2009), Mn (Mohan and Gandhimathi, 2009), Cd (Cho et al., 2005), and Cr (Itskos et al., 2010). Last but not least, fly ash can be used to adsorb ions $\mathrm{Hg}$ (II) (Daci et al., 2011), the heavy metal ions with very high toxic properties.

Fly ash is an adsorbent that is reasonably priced, efficient, simple to prepare, and easy to operate. It can also be used to adsorb heavy metal ions. Pure fly ash was used to adsorb $\mathrm{Hg}$ and $\mathrm{Pb}$ in aqueous solution, but the adsorption capacity for $\mathrm{Hg}$ was fairly low at $17 \%$ (Kuncoro and Fahmi, 2013). Similar results were also demonstrated in a study conducted by Astuti and Mahatmanti (2010) with the adsorption capacity for $\mathrm{Pb}$ ion by $63 \%$. Modification of fly ash into pellets was also conducted by Papandreou et al., (2007), for the adsorption of $\mathrm{Cu}$ (II) and Cd (II). This method was less effective because most of the fly ash mass was lost during the process of adsorption. We need materials that can trap fly ash in order to increase the ability of adsorption, and one of the materials is chitosan.

$\mathrm{Hg}$ is heavy metal which is carcinogenic and potentially threatens human health at very low concentrations. Some data have shown that $\mathrm{Hg}$ can cause damage on brain, kidney, gastrointestinal tract and central nervous system and is toxic to cells by binding the intracellular sulfhydryl groups (Inbaraj et al., 2009). The maximum limit of $\mathrm{Hg}$ level in drinking water is $2.0 \mathrm{\mu g} \mathrm{L}^{-1}$ and the total waste of $\mathrm{Hg}$ ions allowed was at $10.0 \mathrm{\mu g} \mathrm{L}^{-1}$ (Kumar et al., 2013). The purpose of this study was to determine the optimum mass of fly ash-chitosan composite pellets modified with glurataldehyde to lower the concentration of $\mathrm{Hg}^{2+}$ in solution. 
Isna Syauqiah, Umi Baroroh Lili Utami, Meina Wulansari Yusniar: The Effect Of Mass Of

\section{MATERIALS AND METHODS}

The experiment condition that was set was the operational pressure at atmospheric pressure and normal temperature $\pm 30^{\circ} \mathrm{C}$ (room temperature), using composite pellets as the adsorbent during 60 minutes of contact time. Mass of pellets tested was $1 \mathrm{~g}$, $2 \mathrm{~g}$ and $3 \mathrm{~g}$.

\section{Adsorption Process Procedures}

The first step was preparing the $\mathrm{HgSO}_{4}$ solution of $0.0296 \mathrm{ppm}$ which its $\mathrm{pH}$ was set according to the variables specified. The next step was pouring the $100 \mathrm{~mL}$ $\mathrm{HgSO}_{4}$ solution into each Erlenmeyer, and then the composite pellets were added based on variables into each $100 \mathrm{~mL} \mathrm{HgSO} 4$ solution. Each of these Erlenmeyers was put in a shaker, and the speed of shaker of each variable was set for 60 minutes of adsorption time. After the adsorption process was complete, the process was continued to the filtration and the filtrates were analyzed using Atomic Absorption Spectroscopy (AAS).

\section{RESULTS AND DISCUSSION}

The composition of pellet mass of fly ash composite will affect the percentage of adsobpted $\mathrm{Hg}$ ions in the adsorbent (Azouaou, et al., 2013).

Figure 1 is a curve of the relationship between the mass of pellets and the total percentage of $\mathrm{Hg}^{2+}$ adsorbed into fly ash composite pellets. The picture shows that the optimum mass of composite pellets in this study was $2 \mathrm{~g}$ because the greatest amount of $\mathrm{Hg}$ being adsorpted was shown at this point. The mass of $1 \mathrm{~g}$ composite pellets showed very low adsorption of $\mathrm{Hg}$ because the small amount of pellet mass caused the fly ash did not stick so firmly on chitosan for the adsorption process. Most of the mass of fly ash would be lost and reduce the ions percentage of adsorbed $\mathrm{Hg}$. Meanwhile, a mass of $3 \mathrm{~g}$ pellets decreased the percentage of $\mathrm{Hg}$ ions being adsorpted because the great amount of pellet mass will hinder the diffusion process, and thus $\mathrm{Hg}^{2+}$ solution can not penetrate the layer of chitosan outside the pellet and can not be adsorpted on the surface of fly ash.

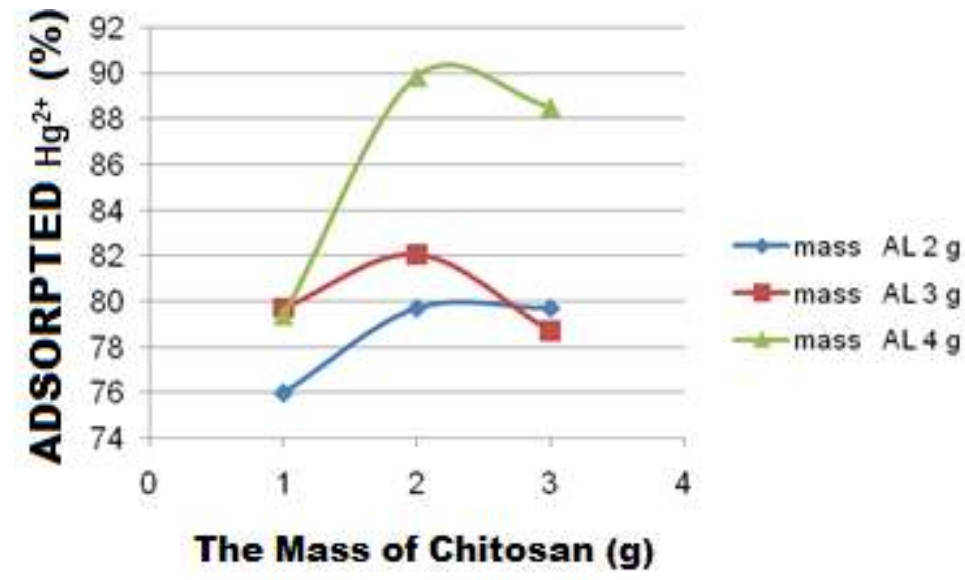

Figure 1 Effect of pellet mass on $\mathrm{Hg}^{2+}$ adsorption capacity in fly ash composite $\mathrm{p}$

\section{CONCLUSION}

The optimum conditions obtained from the adsorbent pellets composite fly ashchitosan cross-linked with glutaraldehyde after contacted with a solution containing $\mathrm{Hg}^{2+}$ is $\mathrm{pH}$ solution at $\mathrm{pH} 6,4 \mathrm{~g}$ fly ash in 20 $\mathrm{ml}$ of chitosan gel; for $2 \mathrm{~g}$ pellets that of optimum stirrer speed at $180 \mathrm{rpm}$. Adsorption of $\mathrm{Hg}^{2+}$ in solution using fly ash pelletchitosan composite reach optimum at fly ash mass $4 \mathrm{~g}, \mathrm{pH} 6$ and the stirring speed of 180 rpm with $89.53 \%$ adsorption capacity.

\section{REFERENCES}

Aksu, Z \& Yener, J. (1999). The usage of Fried Activated Sludge and Fly Ash Wastes in Phenol Biosorption/Adsorption: Comparison with Granular Activated Carbon. Journal of 
Isna Syauqiah, Umi Baroroh Lili Utami, Meina Wulansari Yusniar: The Effect Of Mass Of

Environ Sci Health Part A. 34: 17: 77-96.

Astuti, W. \& Mahatmanti, W.F. (2010). Activation of Coal Fly Ash and Its Application for Lead Adsorbent in Electroplating Waste Treatment. The Faculty of Engineering and Faculty of Mathematics and Natural Sciences. State University of Semarang.

Azouaou, N., Mohamed, B., Hassiba, M. dan Zahra, S. (2013). Adsorption of Lead from Aqueous Solution onto Untreated Orange Barks. The Italian Association of Chemical Engineering 32: 1974-1979.

Cho, H., Oh, D. \& Kim, K. (2005). A Study on Removal Characteristics Of Heavy Metals from Aqueous Solution by Fly Ash. Journal of Hazard Mater $127: 95-187$.

Daci, M.N., Nexhat, M., Daci, L.Z., Gashi, S. \& Hoxha, D. (2011). Coal Ash as Adsorbent for Heavy Metal lons in Standard Solutions; Industrial Wastewater and Streams. Ecohydrology and Hydrobiology 11: 129-132.

Inbaraj, B., Stephen, J.S., Wang, J. F., Lu, F.Y., Siao, B.H. \& Chen (2009). Adsorption of Toxic Mercury (II) by An Extracellular Biopolymer Poly ( $\gamma$-glutamic acid). Bioresource Technology 100: 200-207.

Itskos, G., Koukouzas, N., Vasilatos, C., Megremil \& Moutsatsou, A., (2010). Comparative Uptake Study of Toxic Elements from Aqueous Media by Different Particle-Size-Fractions of Fly Ash. Journal of Hazard Mater 183: 787-92.

Kuncoro, E.P., \& Fahmi, M.Z. (2013). Removal of $\mathrm{Hg}$ and $\mathrm{Pb}$ in Aqueous Solution Using Coal Fly Ash Adsorbent. Procedia Earth and Planetary Science 6: 377-382.

Kumar, A., Krishna. S., Barathi. M., Puvvada, S. \& Rajesh, N. 2013. Microwave Assisted Preparation of Glycidyl Methacrylate Grafted Cellulose Adsorbent for The Effective Adsorption of Mercury from A Coal Fly Ash Sample. Journal of Environmental Chemical Engineering 1: 1359-1367.

Mohan, S., \& Gandhimathi, R., (2009). Removal of heavy metal ions from municipal solid waste leachate using coal fly ash as an adsorbent. Journal of Hazardous Materials 169: 351-359.

Nollet, H., Roels, M., Lutgen, P., Vander Meeren, P., \& Verstraete, W. (2003). Removal of PCBs from wastewater using fly ash. Chemosphere 53: 55-65.

Papandreou, A., Stournaras, C.J. \& Panias, D. (2007).Copper and Cadmium Adsorption on Pellets Made from Fired Coal Fly Ash. Journal of Hazardous Materials 148: 538-547.

Soco, E. \& Kalembkiewicz, J. (2013). Adsorption of Nickel (II) and Copper (II) Ions from Aqueous Solution by Coal Fly Ash. Journal of Environmental Chemical Engineering 1: 581-588

Wang, C., Li, J., Xia, S., Lianjun, W. \& Xiuyun, S. (2009). Evaluation of Zeolites Synthesized from Fly Ash as Potential Adsorbents for Wastewater Containing Heavy Metals. Journal of Environmental Sciences 21: 127-136.

Wang, S. \& Wu, H. (2006). Environmentalbenign utilization of fly ash as lowcost adsorbent. Journal of Hazardous Materials B13: 482501. 